\title{
An Insight into an Egyptian Intangible Cultural Heritage Tradition: The Hammām
}

\section{Mona M. Raafat El-Sayed and Randa Alaa El-Din Fouad}

\begin{abstract}
Looking after one's health and personal hygiene is crucial for the sanity of our minds and souls. Egyptians have always been fastidious about their health and cleanliness since the dawn of history. This fact can be traced as far back as the Pharaonic, through the Graeco-Roman, Byzantine, Islamic, Modern and Contemporary eras. This paper sheds the light on one of the most favourable Egyptian traditions that is still currently in practice, which is "visiting the public bathhouse "Hammām". Bathhouses have always been considered as a social hub for the Egyptians, not only for body care and beautification but also for meeting up with friends. The Hammäm provides us with extremely rich material for our Egyptian intangible cultural heritage. On a final note, it is rational to extrapolate that traditional Hammäms are the nucleus for the contemporary luxurious spas and health clubs.
\end{abstract}

\section{Keywords}

\section{Public Bath - Hammām - Intangible Cultural Heritage - Egypt - Hygiene}

\section{Introduction}

Personal hygiene is a key component of human well-being regardless of religion, culture or place of origin. It is defined as the healthy practices and lifestyle, which helps in the maintenance and promotion of individual health; physically, emotionally, socially and spiritually. Undoubtedly, it has a significant role in every society as an essential-health need. Throughout the history, it has been an integral part of the religion and health-culture of any community around the world. Poor personal hygiene or selfneglect behavior is regarded by many cultures as an offensive conduct or an indication for specific illness, particularly mental disorders. Thus, personal hygiene is not only limited to maintain the cleanliness of the body, but it is strongly connected with the mental and spiritual aspects as well. ${ }^{1}$

Every culture develops its own standards and methods of maintaining personal hygiene that are associated with different personal factors including bathing, clothing, washing hands, grooming the hair, caring for various body parts including the hands, feet, nails, nose, ears, teeth and mouth. ${ }^{2}$

\section{Ancient Egyptian Culture}

Some cultures equated cleanliness and self-caring with godliness and associated hygiene with diverse religious beliefs and practices. For instance, personal hygiene and cleanliness in the ancient Egyptian culture were highly emphasized. They were common features of the religious practices and essential parts of the whole culture. The ancient Egyptians were aware of the diseases that might occur as a result of the lack of self-cleaning and consequently they paid great attention to self-caring and bathed frequently, almost twice daily, to avoid any infection or illness. Priests, in particular, were fixated with cleanliness to the extent that they used to shave their whole bodies every three days and bathed twice a day and twice during the night. ${ }^{3}$

Regarding the ancient Egyptian religion and its relevance to personal hygiene, the Egyptian Book of the Dead entailed a collection of magical and religious spells which stipulate that one cannot speak in the afterlife unless they are pure, clean and presentable. ${ }^{4}$ For example, Spell 125, which deals with the Egyptian ethical standards, prohibits anyone from speaking in the judgment hall unless they are clean, dressed in fresh clothes, shod in white sandals, adorned with eye-paint, and anointed with

\footnotetext{
1 I Clement, Manual of Community Health Nursing (London: Jaypee Brothers Medical Publishers, 2012),70.

2 Clement, Manual, 70.

3 John Wilkinson, Manners and Customs of the Ancient Egyptians (New York: Cambridge University Press, 2013), Vol. 3, 358.

4 John Taylor, Journey Through the Afterlife: Ancient Egyptian Book of the Dead (London: Harvard University Press, 2010), 205.
} 
the finest oil of myrrh. ${ }^{5}$

This strongly reflects the fact of how cleanliness matters in the life and afterlife of the ancient Egyptians. According to Herodotus, $5^{\text {th }}$ century B.C, the ancient Egyptians were the most hygienic and healthy of all nations at that time and they were easily distinguished from other peoples by their manners and customs. ${ }^{6}$ They adopted many of the personal hygiene habits including bathing, washing, and laundering since they were very concerned with cleanliness and bathed frequently. They used to wash their cups, glasses, and plates before and after eating and drinking. Moreover, they exploited the waters of the Nile river, especially in the hot climate days, to bathe and to wash their clothes. They wore freshly washed garments made of linen, which was by far the most common textile. These different daily life practices may refer to the strong bond created between the ancient Egyptians and water through their appreciation for the Nile and their relevant deities. It is worth here to mention that the practices of clothes laundry and bathing in the waters of the Nile river and its canals are ancient Egyptian habits that continue to be existing and are still sighted frequently in some of the rural areas in Egypt till our present day. ${ }^{7}$

Pointing to the importance of self-care and personal hygiene, the ancient Egyptians were aware of the value of bathing to keep them clean, happy and satisfy their oods. The lower social class used to bathe in pools, rivers or canals, but wealthier ancient Egyptians had private baths within their homes with large tubs or basins. Servants would bring waters from the Nile river, carried by hand in clay jars or animal skin containers, to fill the basins since even the Egyptinn of the higher socil ches did not have running water in their homes. In the royal palaces and the private houses of the wealthy, there were private baths with basins or stone shower stalls where the bather would stand on a limestone slab with raised edges and a drain cut in it to dispose of sewage. Running water would have been poured over the head and body through a shower, and stoves were used to heat the water, while lined towels were used for drying. ${ }^{8}$ Some indoor bathing facilities have been revealed in ancient sites such as Tell El-Amarna An example of an elaborate bath with innovative water-supply system can be found inside the house of one of the - $10^{\text {th }}$ dynasty at The ancient Eoyptians bathed nearly on dily basis

The ancient Egyptians bathed nearly on dally basis and they used perfumes or scented water to stay clean and fragrant. Scented natron soaps were used, and their ingredients had antibacterial, anti-fungal and whitening properties as well. This cleansing gent is substantially a mineral salt consisting of hydrated sodium carbonate or sodium sesquicarbonate with small quantities

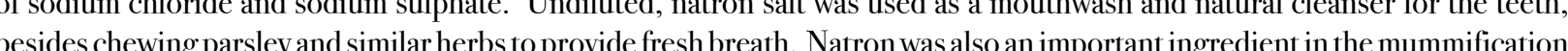
process as it absorbs water and behaves as a drying a a ent. ${ }^{10}$

Other ingredients for cleanliness purposes, described in Ebers Medical Papyrus, ${ }^{11}$ were also used including animal fat and vegetable oils, which were beneficial for moisturizing the skin and fight against different skin diseases. ${ }^{12}$

Deodorants were invented and widely used as mentioned in Ebers Medical Papyrus ${ }^{13}$ that recommends placing a cake of bread mixed with scent under the arms after bathing. Ground carob beans and porridge were used as deodorant..$^{14}$ The mixture of an ostrich egg, a shell of a tortoise and a gallnut of tamarisk is roasted and rubbed to the body of both men and women to expel stinky smell is also highlighted. ${ }^{15}$ Women often had cones of perfumed wax on their heads that would slowly melt
to throughout the day spreading pleasant scent. ${ }^{16}$ Aside from the use of deodorants, the ancient Egyptians were famous for their superior scents and perfumes that their use was mentioned in ancient texts and referred to by several Greek and Roman writers.

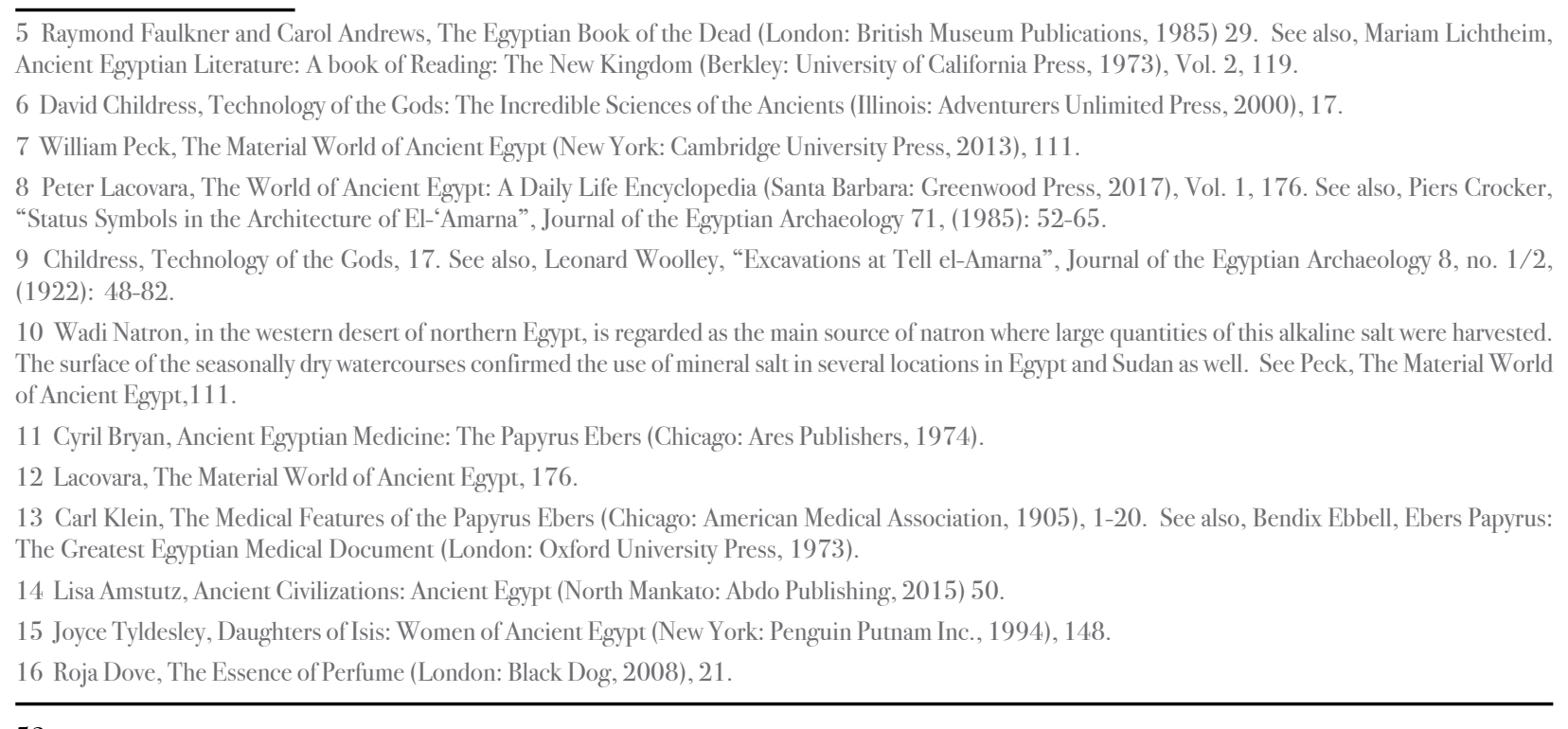

Religiously, it was believed that fragrances were created by the gods in most of the ancient cultures. Consequently, scented offerings or incense formed an important part of ceremonies and rituals along with worship, prayers, and sacrifices. ${ }^{17}$ The ancient Egyptians discovered that any aromatic plant if soaked in oil or melted fat, its scent will transfer to the oil and this

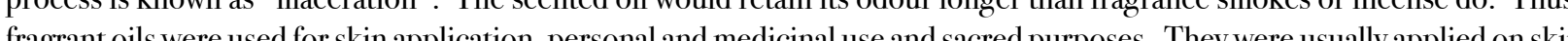

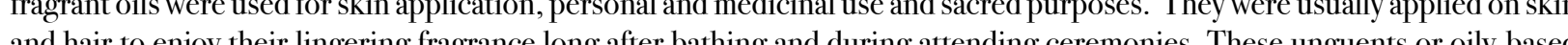

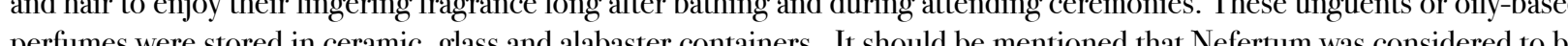
(1) the gol

Ancient Egyptian women were concerned with their personal hygiene, cleanliness, and beauty. They used perfumes and unguents not only to mask their body odours but also to enhance their personal care routines. Myrrh was the favoured fragrance of queen Hatshepsut as it reminded her of the scent of god Amun-Re. She used to rub myrrh at the bottom of her feet so that she would continuously emit pleasant fragrance for herself and others surrounding her wherever she went. Myrrh oil was proved to stimulate the immune system to create white blood cells, when absorbed by the skin and enter the bloodstream. Moreover, it was used as an antiseptic ointment that prevented the heels of the queen from cracking in the hot weather days and provided vitality to her mind and body. ${ }^{19}$ At that time, the Egyptians used opaque glass coloured with metallic oxides in addition to container made out of granite, diorite and especially alabaster carved in adorable animal or lotus shapes to hold the scented oils and keep them cool. ${ }^{20} \mathrm{An}$ alabaster container in the form of a flacon, measuring $4.7 \mathrm{~cm}$., carved with the name of Hatshepsut is currently displayed at the Bonn University Egyptian Museum. It was examined by the German Egyptologist Michael Hoveler-Müller, who was looking for a perfume residue since the shape of the flacon is that of the well-known perfume bottles, as depicted on the walls of Deir el-Bahari Temple, Thebes. After two years of research, he announced that the container did not include a perfume and the substance inside is a kind of skin care lotion or a medication used by the queen for treating eczema"

Ancient Egyptian women knew depilation to get rid of the unwanted body hair and to stay clean and smooth. Shaving body hair was mainly facilitated by applying scented oil to the skin. Beeswax, special oils or cream depilatories made with an alkali, such as quicklime, were also effective in body hair removal and were used as shaving lotions. ${ }^{22}$ Aside from being fashionable, some of the Egyptian women, especially the wealthy, shaved their heads using razors of flint or metal and wore wigs made of human hair the Egyptian women, especially the wealthy, shaved their heads using razors of flint or metal and wore wigs made of human hair
to protect the scalp mainly from the sun's heat and to avoid the infestation of head lice. Women who kept their natural hair used hair extensions or wigs that were carefully woven and knotted to their own hair with beeswax and resin. ${ }^{23}$

As for the males, they paid great attention to their personal hygiene and self-care as well. Upper-class men also shaved their bodies and heads to keep cool and prevent lice infestation. ${ }^{24}$ They used different hair removal tools including tweezers, knives, razors of flint or metal and whetstones. In ceremonial occasions, wealthy men and women wore elaborate wigs made of human hairs, while the worst were made of coarse red date palm fibers. Furthermore, tomb reliefs and paintings show that not only females but also males adorn their heads with perfumed cones to release sweet aroma during the feasts and celebrations. ${ }^{25}$ The performance of male circumcision in ancient Egypt was common among the upper classes and recognised as a puberty rite for the sake of cleanliness. This practice dates back to $6^{\text {th }}$ dynasty when the boys were routinely circumcised between the age of six and twelve. Thus, it marked the transition from boyhood to adulthood and therefore it was not performed in infancy. A male circumcision scene is illustrated on the walls of the tomb of the roval architect Ankhmahor at Saqqara showing details of

17 Jennifer Rhind, Fragrance and Wellbeing: Plant Aromatics and their Influence on the Psyche (London: Jessica Kingsley Publisher, 2014), 90. See also, 18 Rhind, Fragrance and Wellbeing, 90. See also, Donald Redford, The Oxford Encyclopedia of Ancient Egypt (London: Oxford University Press, 2001). Vol. 2. 514-515.

19 Elizanerether Awaken to Healing Fragrance. The Power of Essential Oil Therapv (Berkeley: North Atlantic Books, 2010), 8

20 Jones, Awaken to Healing Fragrance, 6 .

21 University of Bonn, "Deadly medication? Scientists shed light on the dark secret of Queen Hatshepsut's flacon," PHYS. ORG, August 19, 2011. https:

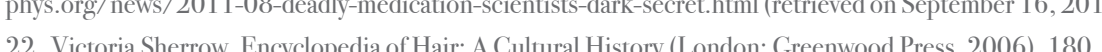

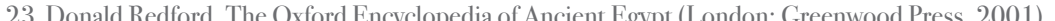

24 Sherrow, Encyclopedio o Hair 180

25 Joyce Salisbury, Encyclopedia of Women in the Ancient World (Santa Barbara: Library of Congress, 2001), 95-96. 
this process and the importance attached to this ceremony. ${ }^{26}$ It should be mentioned that circumcision was primarily enclosed to the priests appealing further purification and cleanliness, and then it was adopted by the nobles and the higher warriors as a hygienic precaution. There is no direct evidence that circumcision was performed for girls. According to the historical records of Herodotus in the $5^{\text {th }}$ century B.C, the majority of the Eovptian upper-class males adopted circumcision for hygienic reasons, and it was conducted by a priest and not a doctor which may indicate that it had more ritual than practical significance ${ }^{27}$

\section{Graeco-Roman Culture}

Practices of personal hygiene and cleanliness of the Greeks were similar to those adopted by the ancient Egyptians. It is noteworthy here to mention that the Latin word "hygiene" is originally derived from the ancient Greek word "hygieia" ('Y Yría or ' $\mathrm{Y} \gamma \varepsilon \dot{\alpha})^{23}{ }^{23}$ in reference to the Greek goddess of health, cleanliness, and sanitation, who is depicted in the classical sculptures as a woman holding a large serpent in her arms. ${ }^{29}$ The Greek hygiene emerged as a specialised medical discipline that attempted to control every aspect of the human environment from air, diet, sleep, works, exercises, daily practices to the passions of
the mind and incorporates them into a sanitary lifestyle. Generally, early Greek hygiene included four mental and physical disciplines, balneology, religion, sport, and medicine. Hippocrates, the founder of medicine and the greatest physician of his time, recommended daily bathing and massaging different oils on the body for good health and optimal relaxation. Moreover, he advised the Greeks on a healthy program known as the Greek Regimen of health, which affirms that the ordinary should focus on both careful diet and regular exercise to acquire a healthy body and healthy mind.

According to the Greek culture, shaving was considered as an aesthetic approach for personal hygiene. The removal of body hair may have been practiced by both ancient Greek men and women as seen through their nude artistic depictions. Ancient Greek women removed their pubic hair because it was thought to be uncivilised to appear in public baths with pubic hair. Shaving body and face hair was also adopted by the Greek rulers especially Alexander the Great who was fixated on shaving and appeared in many scenes and depictions beardless. He even ordered his warriors to shave their faces and bodies before battles so that their enemies fail to grab them by the beard."

The ancient Greeks used different cleansing tools such as the "strigil", which was a Graeco-roman tool used to scrape oil, sand, dirt or perspiration off the skin before bathing. This tool was made out of bronze, shaped like the letter "J" with a looped handle and sometimes inscribed with the name of its owner. Strigit is principally associated with athletes as they used to coat themselves with olive oil before practicing athletic activities. Nevertheless, tomb excavations in an early Ptolemaic grave at Naucratis revealed the discovery of such a tool among women's possessions which indicates that strigil might have been used by Greek women as well for cleaning purposes. ${ }^{32}$

Ancient Greek women were obsessed with their skincare routines and beauty. Olive oil was a necessity for daily personal hygiene and body care. It was used as a beautifying face cleanser, after-bah mosturzer, and a personal lotion. The combination of honey and olive oil was used as an anti-ageing cosmetic product as well. Moreover, wealthy woren were fanous for having night milk and honey baths for extra soll and hydrated skin. For instance, queen Cleopatra used to wrap herself with mud from the Dead Sea, ${ }^{33}$ and bathe daily in donkey milk to preserve the vitality and beauty of her skin. It was said that around 700 donkeys were needed to provide enough milk for her daily use. Unsurprisingly, the lactic acid in the milk was proved to prevent face and body wrinkles, soften and whiten the skin. Almond oil and honey were also added to her bath to achieve radiant and smoother skin. Even today milk and honey are still effective ingredients in cosmetic products used for different skincare practices. ${ }^{34}$

One of the most important innovations that marked the advent of the Greeks into Egypt, was the introduction of "Bathhouses".

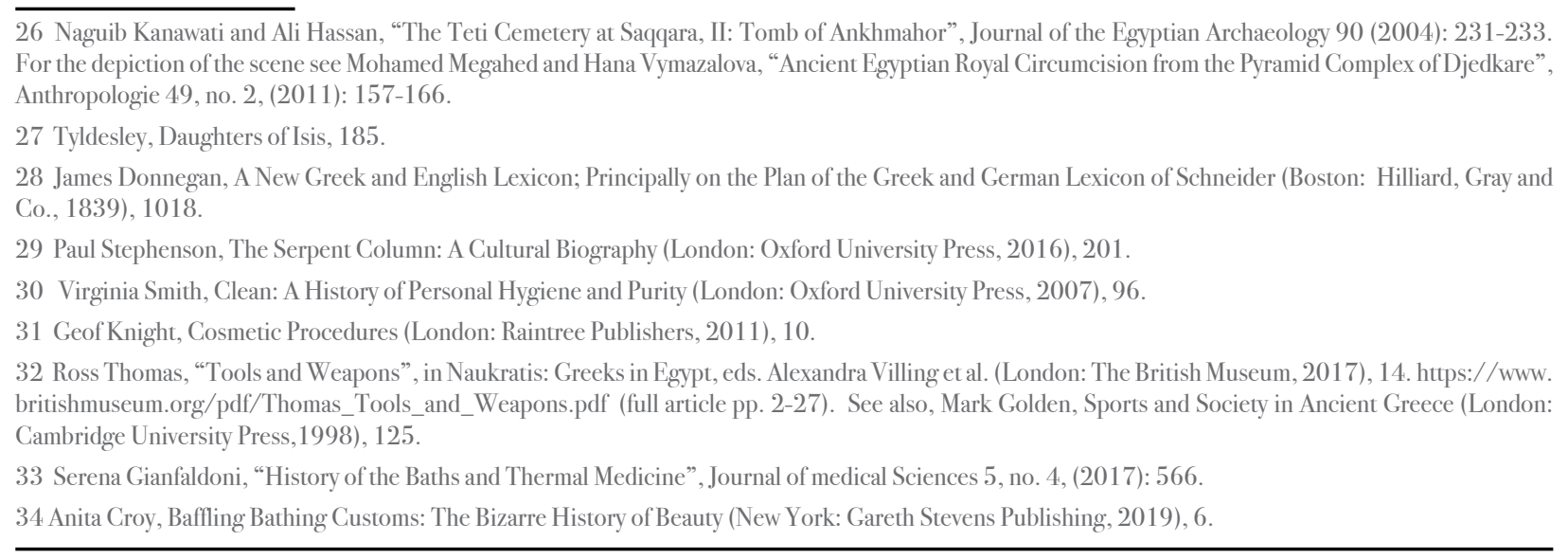

Under the rule of the Ptolemies, a substantial number of Greek public baths were built in Egypt following the original Greek style which includes circular bathing rooms (tholoi), separating men from women, with individual large hip-bathtubs where water was poured directly from jars over the bathers sitting in the tubs. For the earlier Greek baths, water was heated o portable braziers through coal burning or heating up rocks. Later on, the baths consisted of two main sections; a hygienic

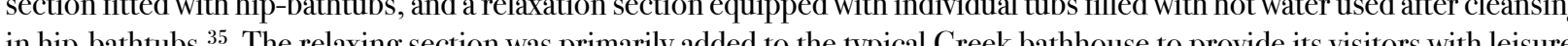
in hip-bathtubs. The relaxing section was primarily added to the typical Greek bahouse to provide its visitors with leisure, pleasur, ald forms of bathing at fountains or stand basins and other amenities, such as massage, are proved to be existing. ${ }^{37}$ Evaristo Brecci discovered the earliest Greek baths of Egypt in 1905 at Taposiris Magna

With the decline of the Greek society and the rise of the Roman empire in Egypt, the Romans adopted much of the Greek philosophy and experience related to health and personal hygiene. They added their own innovations and achievements to the field of public health so that the ordinary people, and not just the rich, could keep clean and hygienic. ${ }^{39}$ They were extremely skilled in the engineering of water supply, particularly the invention of lead or bronze water pipes that brought filtered wate into and arood sewage and drainage systems, public baths, latrines, and medical care. The Romans wer from mosquito-infested swamps and marshes ${ }^{40}$

The ancient Romans were fastidious about their personal hyoiene, appearance, and health. It was crucial to obtain the needed facilities to ensure their ability to bathe and clean themselves. Ancient Romans sometimes bathed several times a day ${ }^{41}$ The Roman baths were not only places for cleanliness and self-caring, but also for social and business interactions in addition to their leisure and health aspects. Sometimes, they served as state propaganda used as a physical reminder for the emperor" beneficence, power, wealth and influence. ${ }^{42}$ Thus, in Roman Egypt, most of the baths were named after Roman emperors such as Tiberius, Nero, Trajan, Hadrian, and Antoninus, seeking for the emperors' honour and satisfaction. Meanwhile, examples as Tiberius, Nero, Trajan, Hadrian, and Antoninus, seeking for the emperors' honour and satisfaction. Meanwhile, examples Nero's intended visit to Alexandria ${ }^{43}$

Roman baths varied in their design, size, decorations, function, and arrangement. By constructing aqueducts, fresh and clean water was easily supplied to baths and fountains. There were special baths for men and women. Mixed bathing was an unusua feature of the Roman culture, however, it happened on a very limited scale. ${ }^{44}$ Other baths allocated specific hours or days for women to bathe and enjoy the existing facilities. Plutarch warned Roman men from bathing with women or using thei baths believing that women's body releases effluvia and excretions that are defiling when absorbed by men. ${ }^{45}$ Archaeological baths believing that women s body releases effluvia and excretions that are defiling when absorbed by men. ${ }^{45}$ Archaeologica excavations revealed the discovery of a wide variety of
the Roman baths were lively and busy social centres. ${ }^{6}$

Both ancient Greeks and Romans used abrasive materials, including pumice stones, for hair removal. ${ }^{47}$ They also used tweezerlike tools and the metal strigil to get rid of the unwanted body hair through applying a depilatory paste made of pitch, she-goat gall, donkey fat, bat blood, and powdered viper. Slaves were required to shave their heads as a mark of their lesser class. Roman emperors paid particular attention to their appearance and personal hygiene. It was said that Emperor Augustus used red-ho nutshells on his legs as a form of depilation and to make the hair grow soft. ${ }^{48}$

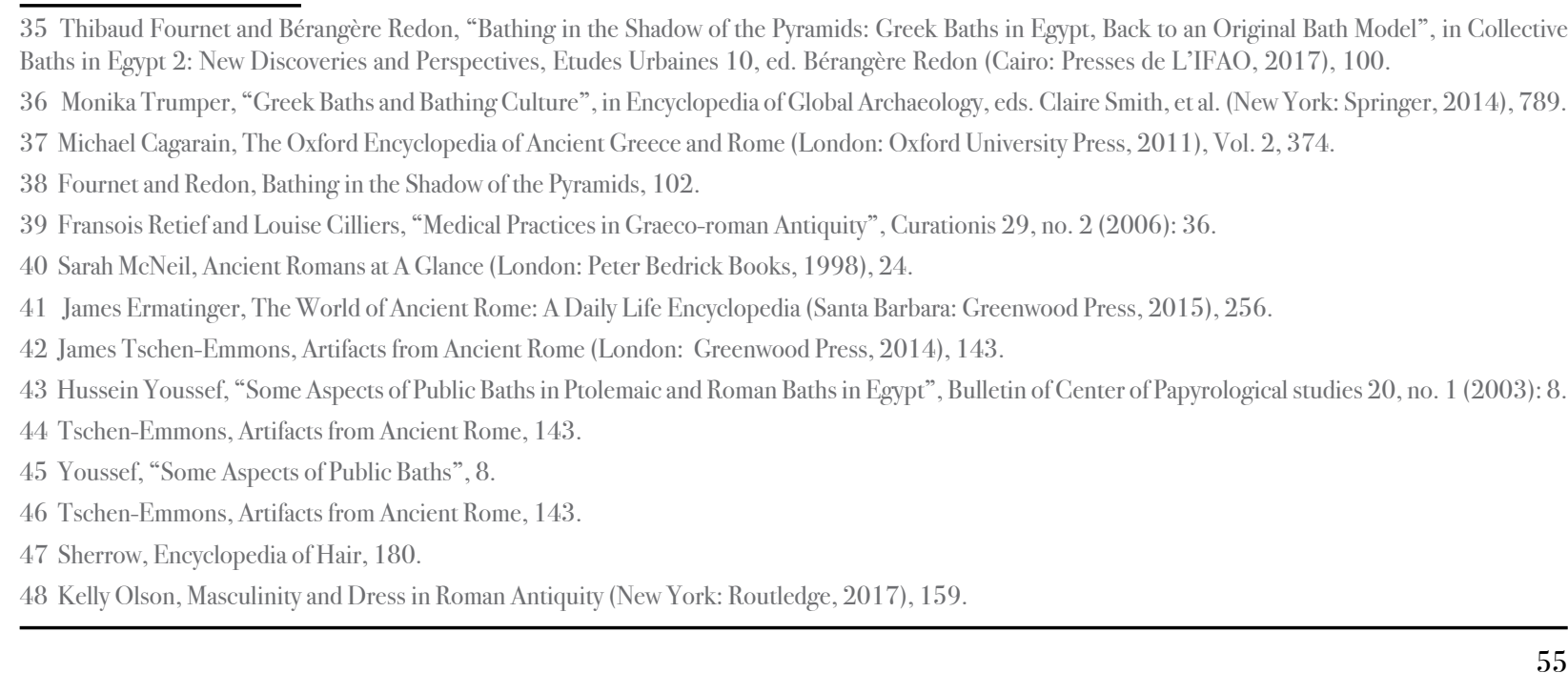


With the beginning of the Roman period in Egypt, the small Greek baths, "tholos" baths, disappeared. The Roman bathhouses were a continuation of the Greek baths and shared a lot of its significant characteristics while following a new layout that differs from the classical Graeco-Egyptian baths. ${ }^{49}$ The new generation of the Roman baths in Egypt, that can be called "GraecoRoman-Egyptian", are hybrid baths sharing specific features of the Graeco-Egyptian baths integrated with the Roman ones. The classical Roman baths commonly include only one or two multifunctional entrance rooms for all activities relevant to bathing "apodyterium, tepidarium" and a single bathing room with a collective heated immersion pool "caldarium". ${ }^{50}$ The best-known hybrid example of the Graeco-Egyptian-Roman baths is located at Tell El-Herr, north Sinai. It combines the traditional elements of the Graeco-Egyptian-Roman architecture represented in hip-bathtubs, individual immersion baths in relaxation rooms, furnace system heating waters and the neighbouring rooms by radiation, possible heating walls and finally baths are organisec Late Ptolemaic and Early Roman Period can be found at Karm El-Barassi, Xios, Hermopolis and possibly the large baths at
Luxor. ${ }^{52}$

According to the finds of the archaeological excavations and the documental evidence, it can be concluded that the majority of the Graeco-roman baths in Egypt were similar in their structure that fundamentally contained four principal rooms: cold water room "Frigidarium", hot air room "Tepidarium", hot water room "Caldarium", and vapor/ Sauna room "Faconicum". The heating system used to warm up the water and air in baths is known as "Hypocaust". Holes where boiled water flows through pipes, under the hot air and the hot water room grounds, to warm them up "Suppressor" were also added. Other rooms
were attached to the baths including room for changing clothes with niches "Opodyterium", waiting room "Ante", and toilets were attached to the baths including room for changing clothes with niches "Opodyterium", waiting room "Ante", and toilets
"Fatrine/Latrine" Additionally, several baths' attachments existed including stores for fuel, oven, water tanks, cleansing. "Fatrine/Latrine". Additionally, several baths" attachments existed including stores for fuel, oven, water tanks, cleansing contrary to poor baths, which lack the presence of these elements. ${ }^{53}$ It is worth here to mention that around forty-six typical Greek baths have been discovered in Egypt and around forty-nine
Roman baths were revealed between the $1^{\text {st }}$ and the $6^{\text {th }}$ century A.D. The majority of these baths are distributed between Syene, Kom Wasit, Athribis, Bi’r Samut, Buto, Dakhla Oasis, Tell el-Herr, Marina El-'Alamein, and others."

During the Late Roman/Byzantine Period, the construction of public baths continued to be a significant feature of the public architecture. The great public bath of Kom El-Dikka in Alexandria, dating back to the second half of the $4^{\text {th }}$ century, is
considered to be the best existing example of baths constructed on imperial standards. The interior design follows the classical Roman bath models except for the Sudatorium or "steam room", which was originally a preferred Greek feature. Almost half of the complex's heated rooms survived together with the underground service systems. ${ }^{55}$

Starting from the $5^{\text {th }}$ Century onwards, the conventional heating techniques developed quite gradually with the installation of steam diffusion devices in the heated rooms. This evolution in the heating techniques helped in reducing the size of tubs and consequently the volume of the hot rooms. The innovation of the steam diffusion devices marked the birth of Hammäm in Egypt, whose main characteristic is heating through steam rather than through the hypocaust's dry heat. ${ }^{56}$

\section{Islamic Culture}

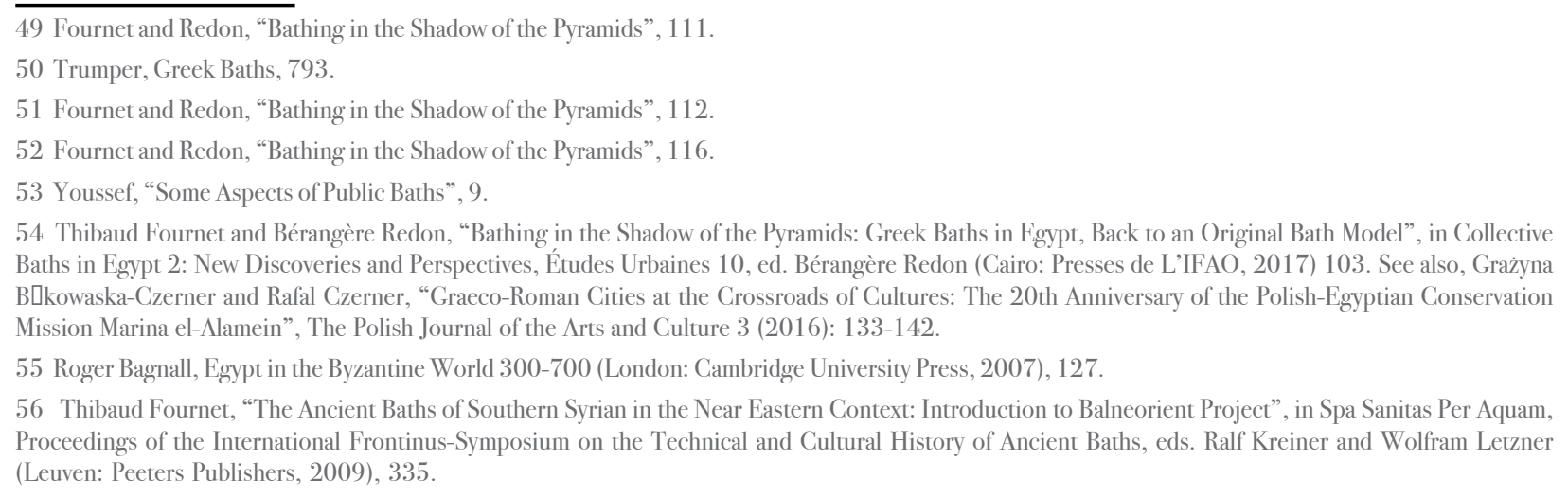

Hammām (or Public Bath) was a key element of the Egyptian urban fabric during the Islamic era. It constituted an integral par of a network of social buildings e.g. Kuttāb (school for young children), Madrasa (religious school) and Zāwya (small prayer hall). The Egyptian community thought of it as a place for social activity e.g. meetings, celebrations and networking as well as somewhere to maintain their well-being and personal hygiene by relaxing and bathing. ${ }^{.5}$ Controversially, hammäms werc conspiracies for example the murder of the famous Shagar el Durr during the Mamluk Period. ${ }^{58}$

As a matter of fact, hammäms were integrated as one of the main components of the Mamluk's socio-economic life in Egyp spanning the period from the $13^{\text {th }}$ to the $16^{\text {th }}$ centuries and continued to be so till at least the $19^{\text {th }}$ century. Arguably, they began to lose hir value by the 1950 s and definitely after the 1960s, especially with the rising westernisation and exposure of the Eontributed to the decrease of public bathsecan a public bious harsh opertict harsh operational regulations imposed by governmental bodies on public baths limited their sustainability and negatively
affected their role in the community. ${ }^{59}$

Subsequent to their introduction to Egypt by the Greeks, bathhouses sustained a rather abundant use throughout the Islamic timeline, especially in Cairo. In fact, it has been recounted by Abdel-Latif al-Baghdadi ${ }^{60}$, that the bathhouses of Cairo were said to be the most "beautiful, spacious and well-planned of the Orient". ${ }^{\circ}$ Although, they are still being favoured in some Nort African and Medicrancen countries, for instance Morocco, their existence in Egypt has suffered a great decline. Undoubtedly, the hammans Umayyad din rise of Islam is associated with a prompt development in the architecture of baths and the consequent adaptation from Roma to lllow " was prevailing during the Greck perod, was substitucd by sing hot water plunge pools "maghtas" as a source of heating in than the advent of Islam. Unnecessary to say that this arrangement was totally appreciated and respected during the Islamic era.

The oldest Egyptian hammäms of the Islamic era were located in the city of al-Fustât ${ }^{64}$, typically adjacent to places of prayer relating to their cleansing function for wudu (partial ablution) or ghosl (full body ablution) performed before prayers. ${ }^{65}$ It is said that the very first one built in the city was dubbed by the Egyptians as the bath of the mouse or "hammäm al-far" and it wa located in the area know as suwicqa al-magariba. The reason for this peculiar name was that when the locals compared it to earlier Roman baths, it was much smaller, so they considered it only fit or a mouse. "The earliest discovered bath dates back caravanserais (hotels for traders). One of the main reasons for their proximity to the capital, was related to being near adequate

ece and Development in the Arab World, ed. Fekri Hassan. Aloisia de Trafford, and Youssef Mohsen (Alexandria: Bibliotheca Alexandrina, 2008), 229.

58 Heba Youssef, "La Toilette Feminine al'Epoque Fatimide en Egypte", (MSc. thesss, Helwan University, 1995), 26.

59 Fodil Fadli and Magda Sibley, “The Historic Hammåms of Cairo", Journal of Architectural Conservation 14, no 3, (2008): 69.

60 A physician from Baghdad who wrote an account on Cairo after visiting it in AD 1231

61 Nicholas Warner, "Taking the Plunge: The Development and Use of the Cairene Bathiouse". In Historians in Cairo: Essays in Honor of George Scanlon ed. Jill Edwards (Cairo, New York:The American University in Cairo Press, 2002). p. 49-50.

62 Magda Sibley and lain Jackson, "The Architecture of Ilsamic Public Baths of North Africa and the Middle East: An Analysis of their Internal Spatial
Configurations". Architectural Research Quarterly 16, no. 2 (June 2012): 155. 63 Sarab Atassi and Roula Abou Khater, "The Hammam in the Mediterranean Region: Architectural, Urban and Social Dimensions - A Multidimensiona Approach", In An Urban Space, Hammam Rehabilitation Reader, eds. Heidi Dumreicher, Richard S. Levine and Magda Sibley-Behloul (Austria: Sonderrzaht

政

65 Warner, "Taking the Plunge", 49-50.

66 Youssef, "La Toilette Feminine", 31.

7 Warner, "Taking the Plunge", 69. 
urban water distribution system, where saqqas (water carriers) followed a specific pre-set route. Even though, most of the hammäms had their own bi'r (well), but it was not sufficient for the overall usage to fill their cisterns and tanks, especially during the hot summer month ${ }^{6}$. Hence the water supply system was dependent on the water carriers "saqqas" who would store the water in adjacent water cisterns or fountains "sabils", which formed beautiful architectural fundamental components of the city. ${ }^{69}$ Looking after one's personal hygiene was an important issue for the Egyptians during the Ottoman Period, as it had been reported that the number of daily visitors to a modestly sized bathhouse was around fifty to sixty users. This was deduced from the number of towels used per day ${ }^{70}$

Unfortunately, the surviving hammäms in Cairo are in all in a bad condition. Five of them were either restored during the past decade or still under restoration by the $\mathrm{MoA}^{71}$. However, even after their restoration, they remain closed. The question now is decade ar ill the he used as ' 'mat a likely

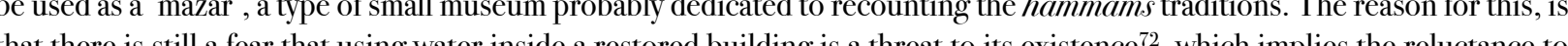

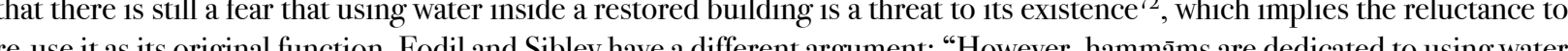
c-lo we water wate." As a therestorationprocess. ${ }^{73}$

Regarding the numbers of hammäms recorded in Cairo over the last few centuries. According to El Kerdany, Al-Maqrīzī (early $15^{\text {th }}$ Century $\mathrm{AD}$ ) identified 52 hammäms which increased to 80 during the $18^{\text {th }}$ century. Whilst the scientists of the French Expedition observed 72 baths in the early19 $9^{\text {th }}$ century. The Tawfiqī plans "khitat tawfigiä" of Ali Pasha Mubarak counted 62 hammäms. ${ }^{74}$ At the time of writing his book (1860). Edward William Lane recognised the number of 60 or 70 functioning hammäms. They ranged between male-only baths, female-only baths or both male/female baths with special times being allocated for each sex, the latter type being the most common ${ }^{75}$ Subsequently, in 1933, Edmond Pauty stated, in MIFAO Vol 64 on Cairo hammäms ${ }^{76}$ that there were around 47 buildinoss. Andre Raymond recorded 33 hammäms in use in $1969^{77}$ In 2004, Nicholas Warner documented 17 hammäms within the area of Historic Cairo ${ }^{78}$. Two other hammäms were identified by Mimar Group as part of their EC-funded research entitled "HAMMAM"79, outside the area studied by Warner. These are known as: hammäm al-Tanbālī, and Bāb al-Bāhr, both located in Bāb al-Sharevah. Four other hammäms in Bulāq Abu el-Elā, were recognised as part of the study prepared by Magda Abdul-Moneim in $2007^{80}$. The total number of hammäms still existent in 2007 mounted up to 23 , each at a different state of deterioration or collapse, only 6 of which were still being used ${ }^{81}$. The surviving historic hammäm.s. ${ }^{g^{2}}$ are in a seriously deteriorated state of preservation threatening to completely disintegrate in a

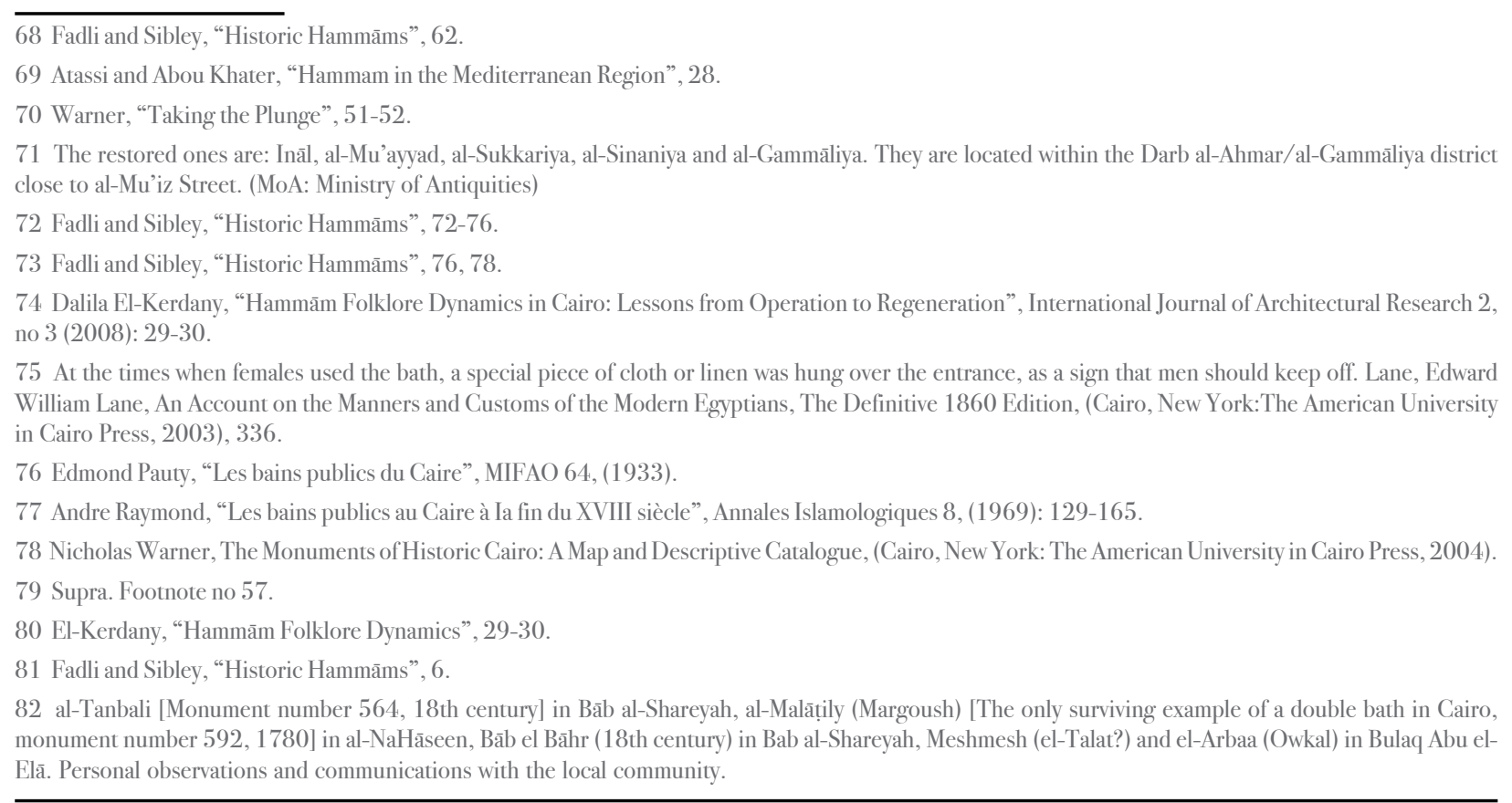

short period of time. Even the ones that have been recently restored by the MoA are not re-used as their original function, bu are used for cultural activities e.g. hammām Ināl and al-Mu'ayyad. ${ }^{83}$

On the other hand, the prevalence of private baths in Cairo is debatable. The distribution of hammäms could hint at the social and economic class of the district. Moreover, their quantity and commonness were a clear indication of the city's development and civilisation ${ }^{84}$ However, it seemed that the higher social class had the privilege of owning their own private baths within the premises of their homes, some dignitaries even had more than one. Even some privatelyowned baths of wealthy people were later opened to the public. Nevertheless, sometimes they could go there on special occasions or for the sake of meeting up with their friends. It could be speculated that Middle class constituted the main portion of public bath users, while the poor or lower social class who could not afford the expenses, often bathed in the Nile. On some occasions, well-to-do people also preferred to bathe in the Nile especially during the summer months ${ }^{85}$ due to the hot weather as well as for the well-known therapeutic value of the Nile's flowing waters. It is even said that the viceroy of Egypt during the mid-nineteenth century, Saeed Pasha, had a bathing kiosk constructed on the Nile, into which a bath suspended on a chain could be lowered. ${ }^{86}$

Well-to-do women went less frequently than men, but on special occasions the baths were hired forall-female private celebration e.eg., pre-wedding parties or a "khilwa", where one of the inner chambers will be specified. Female singers or dancers may also be hired to accompany the festivities. Women were often accompanied by young children, either boys or girls. Occasionally, they take with them all needed snacks, drinks and even their personal towels, soap and water. Rich ladies might choose to be accompanied by their own personal-care maids, known as "bellāneh" or "māshtah" for washing and massaging them. Women often displayed their jewellery and preferred accessories as they considered going to the bath an occasion for showing off. Sonc girls could even be lucky enough to be chosen as brides for the sons of wealthy women during their visits to the baths."

An interesting superstitious belief linked bathhouses with “djinn" (genies or even devils). Al-Qalaqashandii claimed that the first hammäm was created by prophet Sulaiman/Solomon's genies for his wedding with Balquees, where she was supposed to be prepared for marriage ${ }^{89} \mathrm{~A}$ common belieflinked genies with bathrooms, bath houses, rivers and latrines, thus it was customary to utter a small praver "do'aa" before entering any of those areas (by passing over the threshold preferably with the left foot). Once they are in, they should refrain from reciting Qura'n or praying unless absolutely necessary. ${ }^{90} \mathrm{~A}$ rather interesting conce is cited by Nicholas Warner, he states: "A late sixteenth-century treatise on bathing practice by al-Minawi- The Book of the Gloriously Pure Way Concerning Legal and Medical Regulations that Govern the Bath-contains ample references that liken the bath to hell, with its scalding waters, darkness and naked bodies ("as naked as on the day of resurrection")" 91 The hammam provides us with an extremely rich material for Egyptian intangible cultural heritage ranging from the traditiona wooden slippers "qubqāb" worn at the bath to avoid slipping, hhe songs, poems and sayings related to going to and emerging

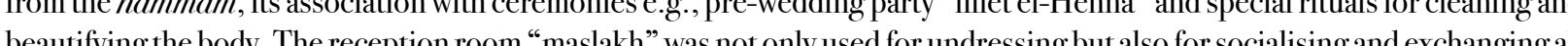
sort of neighbourhood cossip or even for matchmaking process for women and for informal business or social or even politica . overanertendedperiodoftime To fully understand the importanced

of the bathing culture of the Egyptians, it is important to contemplate on the frequency of

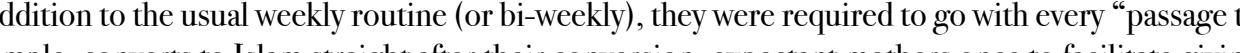
life/new

\section{El-Kerdany, "Hammām Folklore Dynamics", 30.}

84. Atassi and Abou Khater. "Hammam in the Mediterranean Region", 24

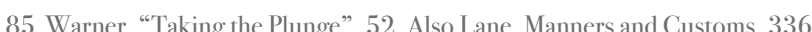

86 Warner, "Taking the Plunge", 75 (note 26 .

87 Lane, Manners and Customs, 343

88 Born in a village in the Nile Delta, al-Qaalaqashandi was scribe of the scroll “katib al-darj” " in the Mamluk chancery in Cairo. He is the author of Subh al-a's sha. 89 Youssef, "LaToilette Feminine", 27.

90 Lane, Manners and Customs

91 Warner, “Taking the

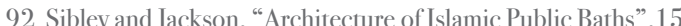


birth then forty days later after delivery for purification, circumcised boys a week after their circumcision. However, the most mportant event par excellence was marriage. As mentioned before, girls might even get chosen as prospective wives as a result of being observed in the hammām ${ }^{3}$. Wedding rituals start, for both sexes, by a glamorous parade to the baths (accompanied by family and friends), where the bride was transported there in a special carriage "maHmal". Sometimes, female singers/dancers "aalemas" were appointed to complete the all-female celebration. This parade was known as "Zaffet al-hammām". In most of the cases, the hammām would be fully hired for the occasion. ${ }^{94}$ Thus the visit to the hammäms formed a rather important part of women's lives, as their outings were normally limited except for these special visits that were mainly linked with happy occasions and festivities ${ }^{95}$. It could be concluded that a substantial array of local customs and traditions were performed at the bathhouses, thus highly contributing to our intangible cultural heritage.

The frequency of visiting the bathhouse was a clear indication of how the Egyptians living in the capital during the Middle Ages highly regarded cleanliness and personal hygiene. Al-Makrizi recounts his bathing experience during the Ninth Century $\mathrm{AD}$. He was visiting the city of al-Fustât and could not find any hammäm with vacancy until his fourth attempt, where he was even served by a "novice". He explains that in the first hammäm that he visited, there were no less than seventy bathers. ${ }^{96}$ It is obvious that all social classes looked after their personal hygiene, bathing for at least once a week (in the Nile for the poorer categories), while the higher social class could use the baths twice per week. The distribution of hammäms around the more elevated Cairene districts, suggests that they were predominantly used by the Middle class. ${ }^{97}$

The city of Cairo has always been reputed for its relatively large number of well-designed and beautifully decorated hammäms. They were constructed of different materials such as stone and brick covered in plaster, with some examples where the brick copula in the ceiling of the undressing room is replaced by a large wooden ceiling surrounded by windows and topped by a lantern "shokhsheka" reason, the entrance was always small and narrow [not to mention discreet], yet it was also usually grandly framed, ornamented [mostly with Arabic calligraphy] with stalactites and painted in bright colours, perhaps to allude to the tranquility that could be found within. Hammäms were clearly thought of as places of relaxation and rest in the busy urban chaos of Cairo. ${ }^{99}$ The typical basic structure of an Ottoman public bath consisted of three main sections: an outer section comprising the
entrance "madkhal", which is typically discreet and leads to the undressing room "meslakh", which is the most decorated room and normally includes a fountain of cold water or "faskeya" which has an octagonal base as a centrepiece, through a benched corridor. This is where people undress/dress, socialise, rest and enjoy food and drink, as in some cases, it may also contain a stall for coffee for the bathers' convenience. Each bench is furnished with either a mattress and cushions or a simple mat according to the status of its userr. ${ }^{100}$ The ceiling contains wooden beams where towels used by bathers were hung to naturally dry. It was designed as a large square room with high wooden ceilings up to ten metres in height. Another narrow and benched dry. It was designed as a large square room with high wooden ceilings up to ten metres in height. Another narrow and benched
corridor leads to the second main space of the hammäm, "bayt 'awal" (or first chamber) 101 . This is a small warm room which acts as a bumper/ transition zone between the cold changing room and the inner hot bathing rooms. "Bayt al-Harara" (hot room), which is the main bathing space consisting of a cross-shaped space organised centrally around the central space saHn ${ }^{102}$. This room is normally cruciform with four marble "leewans" or iwans on the sides and a hot-water fountain rising from a high octagonal base cased with white and black marble and pieces of red tiles, in the centre. In other words, it serves as a "central hub" surrounded by the annexing rooms in a cruciform setting. ${ }^{103}$

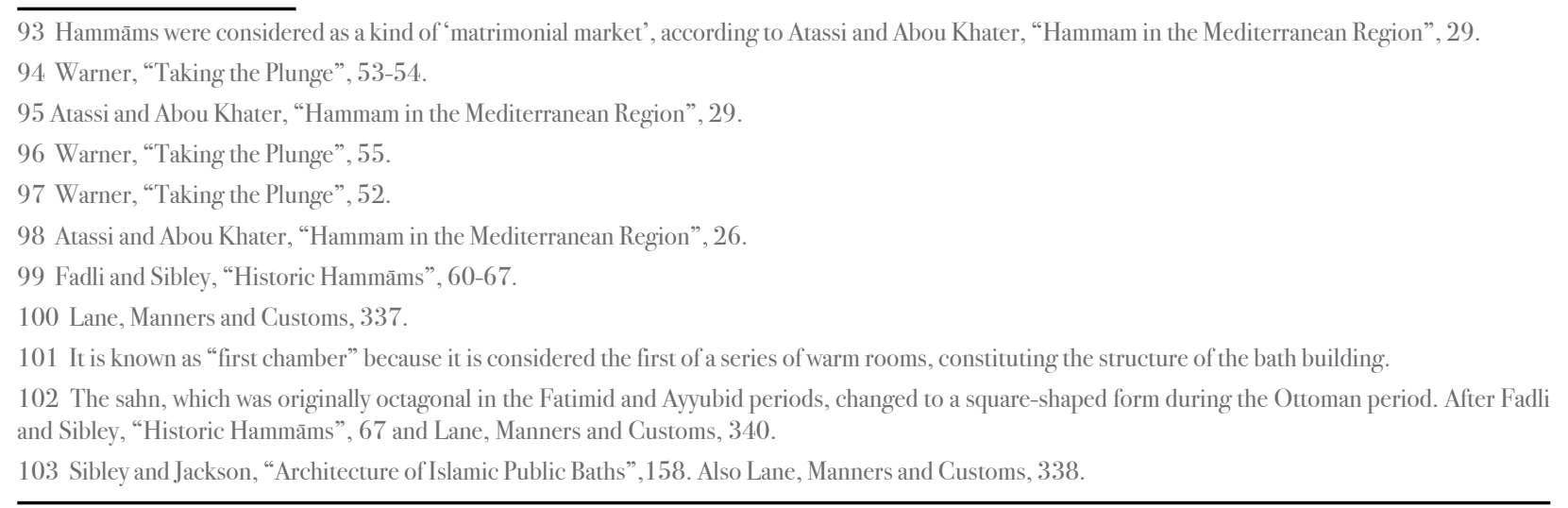

The facade of the bath was mainly decorated with patterns similar to facades of mosques but more elaborate (sometimes coloured in red and white or other colours). The next or middle section contains a series of rooms some of which contain a maghtas (deep plunge pool) and also another room known as the "Hanafeeyeh" (tap). The "maghtas" is approached through a flight of steps and is mainly used for dipping in the warm water which streams into the tank through an opening in the dome of the chamber while the "Hanafeeyeh" is the room which contains two taps; one cold and one hot, placed upon a basin for supplying the water to the bath. There could be one or more of these chambers, i.e.. "maghtas" or "Hanafeeveh". The "saHn" is surrounded by three to four iwans (side rooms) and two types of small rooms called "khilwa" (private space). The "maghtas", which appeared during the Mamluk period, consisted of an elevated small room with an inserted hot water plunge pool. 104

Located on the top of one of the plunge rooms is the third and innermost section, "mustawqid" (furnace or heating system), which is considered to be the "heart" of the hammäm. It is not accessible through any of the afore-mentioned rooms and is only connected to the bathing spaces through copper water pipes and could not be seen by the users. The heating system work for the whole building through smoke and steam travelling under-lloor/hrough-the-walls channels which heats the rooms as well as direct heating for the water tank. Water is transferred to the bathing spaces and the plunge pools through a unique gravitational system. In the of the carlicst descriptionsol hammans, Abdel-Lait al-Baghdadi explains that the furnace has an open dome from which the lames seach a platform with four copper cauldrons "nat assa". The floor of the fireplace is covered with layers of a considered as good sustainabity practices, such as the feyeng of rubbish and he re-use of he by-prodtectsollocal tradition workshops as fint. An the Jackson, hc healo sy thet ater pools releasing heatand steam into the bathing ${ }^{108}$

The middle section customarily has a ceiling in the shape of several domes covering each room. The domes are dotted with coloured glass apertures imitating a "starlit sky", locally called "qamariyāt", strategically positioned to provide beautiful coloured glass apertures initaing " sult sky", locally called " qanariya", strategically positioned to provide beautifi

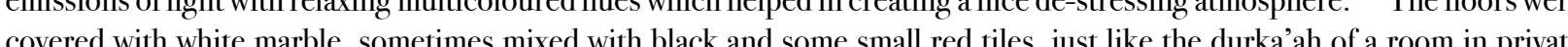
house The building morials ranged between bricks and plaster, which was not a jery good choice due to the emission of

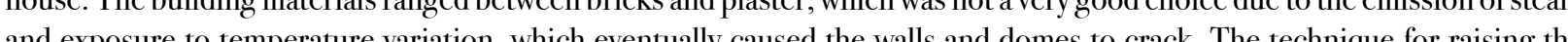
water from the well to the boiler was throg was normally placed on one of the higher levels of the building.

People mostly undressed in the "meslakh" during the spring or summer months, while they prefer to use an inner closed room, "bayt-awwal", during the cooler seasons of autumn or winter. In this area, one could also find two or three restrooms/bathrooms. The servant/attendant (normally a young beardless boy), aka the "lawingee" - which is how the contemporary Egyptians use to pronounce the term "leewangee " (or "leewan "keeper) - would then provide the bather with a number of towels (up to five)

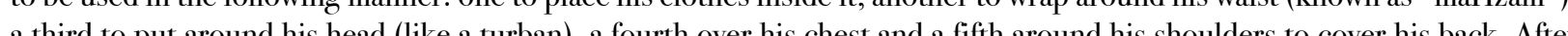
chamber). ${ }^{11}$

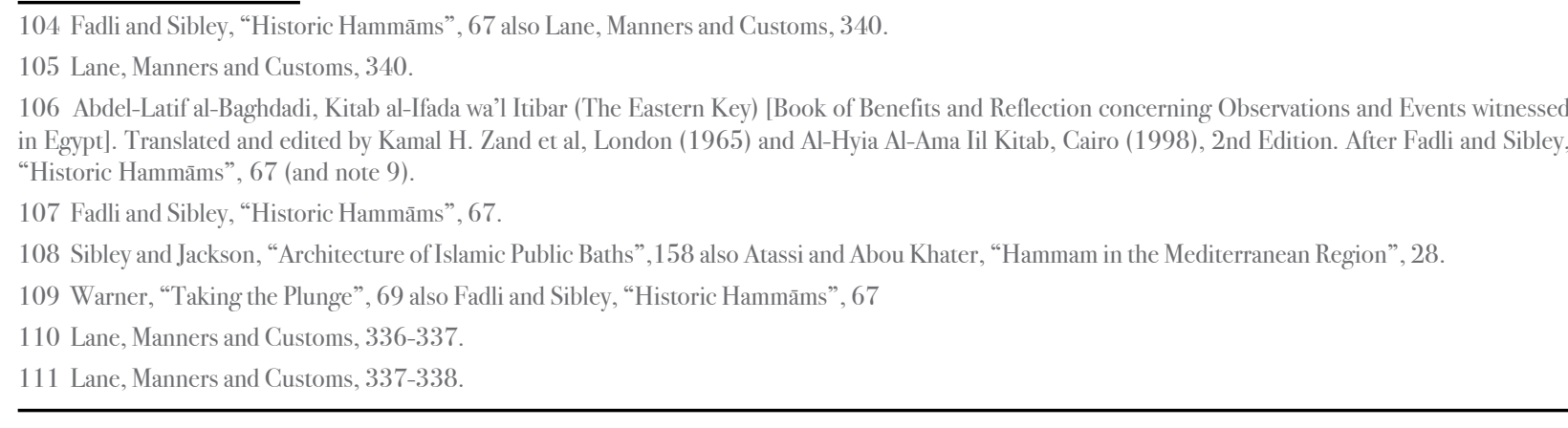


The bathing rituals in the hammāms of the Mediterranean region are described by Sibley and Jackson as follows: "The bathing ritual in the hammāms of the Mediterranean region follows almost the same sequence with slight variations. The body is never entirely exposed to the gaze of other bathers and is traditionally wrapped in a 'fouta', a cotton towel. After sweating in the hot coom and then having their body scrubbed by a hammām attendant, the bathers wash their body facing the individual stone or The body. The bater stich place in sectark

but also of different levels of natural light and privacy, in order to perform different body treatments. The scrubbing of the body

Ironically, it was believed that the level of cleanliness was measured by the sound of clapping the hands on the body, the louder the clap the cleaner the body! After finishing the bath, massage was offered, either with or without oil then later the next offered and orpiment. Epilation was mostly performed in aseparate private room or "Khilwa". 114

Concerning the cost of using the public baths, it didn't seem to be very high. According to the Jewish Geniza, a person was estimated to pay five loaves of bread. ${ }^{115}$ According to Lane in 1860 , a full treatment at the hammäm costed around a piaster estimated to pay live loaves of bread. Aconding thaster (this could mount up to four piasters if adding the tips of the bath atendants). It could erencost less for a simple rinse with soap
andwater. ${ }^{16}$

As regards to the health benefits of visiting the bath houses, they were thought to have both physical and psychological advantages Orone's health. A person was supposed to $g$ o there to clear his mind as well as to revive his exhausted body by relaxing getting a massage done and enjoving taking a plunge in the deep hot tub after a long day's work. An important action was to go to the bath massage done and enjoying taking a plunge in the deep hot tub after a long day's work. An important action was to go to the bath to feel thatyou are completely cured and wash away all traces of the disease. ${ }^{117}$

Hammäms also had a good share of contribution to the socio-economic structure of the Egyptian state, as several jobs were provided to the locals. Any public bath offered at least six different types of jobs, e. $g$, manager "al-maalem or al-maalema", observer "al-nātur or al-nătura", masseur "al-ballān or al-ballāna", hairdresser "al-māshit or al-māshita", rubbish collector "alqamimi” and heating technician "al-waqqād" plus of course some extra personnel as assistants ${ }^{118}$. The previous set of jobs emphasise how the Egyptians seriously considered the body hygiene and personal care.

Once one enters the bath, the "ma'lem" (or keeper of the bath) greets him, then is supposed to hand in his personal belongings for safe keeping. Consequently, he appoints a servant to tend to the user's needs starting by taking off the shoes and supplying a pair of wooden clogs then leading to the "meslakh". ${ }^{119}$ The user then proceeds to the middle section which includes the plunge pool and the tap room, which are also known as the heated rooms or "beit al-Hararah". Once inside, the user starts to sweat as a result of the hot and steamy atmosphere, he is immediately tended by the "mukeyyisatee" (or the massager) who starts to knead his body and tracks his joints in a specific skilled manner which is both relaxing and medicating to make the joints supple.

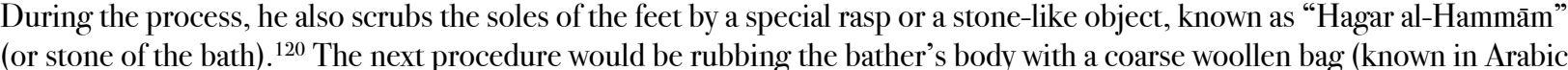

112 Sibley and Jackson, "Architecture of Islamic Public Baths", 155

113 This service was offered as recommended every forty days.

114 Warner, "Taking the Plunge", 64

115 Shelomo Dov Goitein, A Mediterranean Society: The Jewish Community of the Arab World as portrayed in the Documents of the Cairo Geniza, (Berkley,

116 Lane, Manners and Customs, 342 .

117 The latter information was recorded in the Geniza

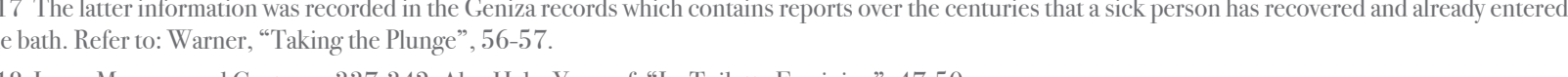

,

20 There were two kinds of rasps that were used; one which is very rough and porous, while the other is of finer texture depending on the roughness of the
kin. The rasps used for the ladies were sometimes covered with a thin layer of silver as "kees"). This act is known as "takyees", hence the name of the "mukeyyisatee". After this point, the bather can have a dip in the "maghtas" or proceed to the "Hanfeeyeh" where he is lathered by a "leef" (or fibres of the palm tree of Hejaz i.e. Saud

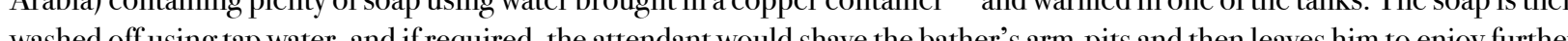
washing as he pleases. Jor a do the cushioned mattresses for a while if he wants and enjoys a cup of coffee and so

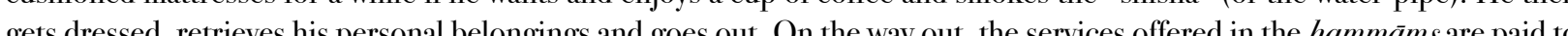
gench

\section{Modern/Contemporary Culture}

In 2019 , there is only a handful of surviving hammäms ${ }^{123}$ that are still fully operational in Cairo. Two of them are historic and are under the supervision of the Ministry of Antiquities; Bāb al-Bāhr and al-Malațilly (Margoush) ${ }^{124}$. They are known by the locals as "Hammäm Balady" or "Hammäm Shaaby" (local bathhouse). The structure of the modernly built ones is highly evocative of older hammams. Additionally, the oflered services underwent negligible change. The main difference is that is not visited by the "Middle-Classed" Egyptians as it used to, but mostly by the lower social class or the local communities. ${ }^{122}$

The recent decline of bathhouses could be attributed to several socio-economic reasons, for example: religious beliefs, modesty, hygiene, convenience or financial causes. Moreover, in our modern-day society, public baths are unfortunately linked to negative two different times of the day or to separate buildings. ${ }^{126}$

The different reasons for clients to use versus not use the bathhouses were incorporated in a study published in 2010. Dina Shehayeb ${ }^{127}$ investigated together with her team members - as a part of a larger research study - a number of public baths in five countries: Morocco, Algeria, Egypt, Syria and Turkey. Two hammäms were studied in Cairo: al-Tanbali and Bāb al-Bāhr. Participatory observation, interviews and questionnaires were all used to complete the survey. The results concluded indicated that there was a clear benefit, whether health, beauty or social values (celebrations of pre-wedding or childbirth) for the bath users, while the non-users were reluctant to go for many reasons; for example: bad reputation ${ }^{128}$, poor hygiene and mostly lack of privacy (people being shy of sharing a bathing experience with strangers). Hence, health hazards, moral judgment, and ignorance of its benefits are three main challenges facing the future of the use of hammäms in Cairo. However, there could be an interest to use the hammäm if certain conditions were changed such as: certified cleanliness of water, repair and contemporary upkeep, additional services such as a gym and service of food and beverage, and the option to go through the
bathing process in less time. Another important factor that could affect women in particular, is allocating a discreet entrance

121 Apparently, the tap water was not suitable for lathering with soap due to its brackish (saline) nature as it comes from a well.

122 All the above mentioned services were charged for one piaster, but the bather could choose to pay extra (up to 4 piasters) as a kind of tips. He can also par

123 al-Tanbali iMonument number 564, 18th centuryy in Bäb al-Shăreyah, al-Malătily (Margoush) [The only surviving example of a double bath in Cairo
monument The latter two are modernly-built. (Personal observations and communications with the local community).

124 Segelat wezaret al-äthâr (Records of the MoA).

125 Marcus Benigno, "Cogs in the wheel: A day in the life of a hammam attendant", Egypt Independant, June 11, 2012. https:// egyptindependent.com/ cogs-wheel-day-life-hat
Accessed on $3 / 8 / 2019$

126 Mohammed Hocine Benkheira, "Hammam, nudité et ordre moral dans l'Islam médiéval (1)", Revue de l'histoire de religions (en-ligne) 224, no. 3

127 Dina Shehayeb, "Survival of the Mediterranean Hammam in Contemporary Societies", HBRC (Housing and Building National Research Center) Journal
Special Iscue (2010) $1-17$ The The

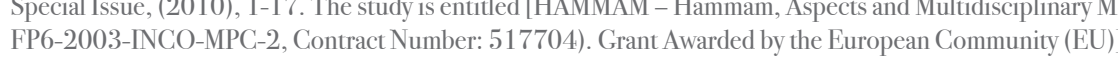

128 In December 2014, an Egyptian TV presenter initiated a police raid on the Băb al-Bahr hammàm, where she secretly filmed scenes Implying male homosexuality within the bathhouse. As a result, the place was closed for further investigations. Later on, the case was dismissed because the allegations coul

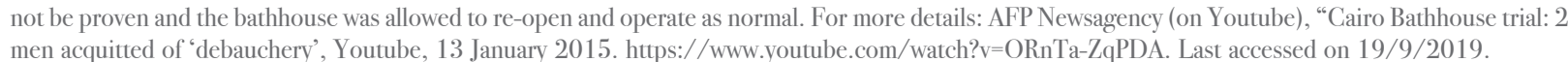


especially in commercial streets like the case of Bāb al-Bahr, for example.

On another note, the middle and higher social classes have found a convenient replacement offered by luxurious health clubs and spas that are available in most high calibre hotels or social sporting clubs. Customers of these establishments receive deluxe body-care or skin treatments as well as sumptuous massages. However, these modern services are more inclined to offer bodycare and beautification therapies on personal basis rather than being a place for social gatherings. On the other hand, it is also worth-mentioning that pre-marriage preparations and special celebrations e.g. "lillet el-Henna" (male or female) are still enjoyed in groups within these facilities.

\section{Conclusions}

Looking after one's health and personal hygiene is crucial for the sanity of our minds and souls. Egyptians have always been fastidious about their health and cleanliness since the dawn of history. This fact could be traced as far back as the Pharaonic civilisation, through the Graeco-Roman, Byzantine, Islamic, Modern and Contemporary eras. The ancient Egyptians considered bathing linked with religious purity, which is also relevant to our contemporary religious beliefs. The Greeks introduced public baths to Egypt and encouraged their use. This practice was promptly welcomed and even favoured by the Egyptians. Bathhouses increased in number steadily over the ages, noting some changes in their structure or heating techniques but they always main up with friends. Unfortunately, over the past decades, he use of traditional public baths has suffered a great decline due to several reasons e.g., level of cleanliness, change of religious beliefs or even bad steretypes. But on the other hand, a new type of establistments evolved to ater for the needs of higher social class, like health lubs or spas which are mostly located in high callibre hotels. However, hese modern services are more indlined to offer body care and beatufication therapies e.g., massage on skin

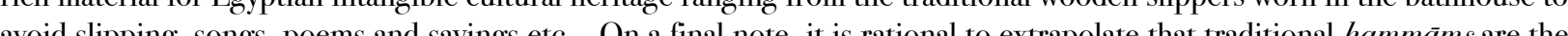

\section{Bibliography:}

AFP Newsagency (on Youtube), “Cairo Bathhouse trial: 26 men acquitted of 'debauchery', Youtube, 13 January 2015 htps.//www youtube.com/watch?

Amstutz, Lisa. Ancient Civilizations: Ancient Egypt. North Mankato: Abdo Publishing, 2015.

Atassi, Sarab and Abou Khater, Roula. “The Hammam in the Mediterranean Region: Architectural, Urbanand Social Dimension - A Multidimensional Approach". In An Urban Space, Hammam Rehabilitation Reader, edited by Heidi Dumreicher, Richard S. Levineand Magda Sibley-Behloul, 23-32. Austria: Sonderrzahl Verlag, 2013.

Bakowaska-Czerner, Grażna, and Rafal Czerner. "Graeco-Roman Cities at the Crossroads of Cultures: The $20^{\text {th }}$ Anniversary of the Polish-Egyptian Conservation Mission Marina el-Alamein.”, The Polish Journal of the Arts and Culture 3 (2016): 133-

Bagnall, Roger. Egypt in the Byzantine World 300-700. London: Cambridge University Press, 2007.

Benigno, Marcus. “Cogs in the wheel: A day in the life of a hammam attendant", Egypt Independant, June 11, 2012. https:// egyptindependent.com/cogs-wheel-day-life-hammam-attendant/ Accessed on 3/8/2019

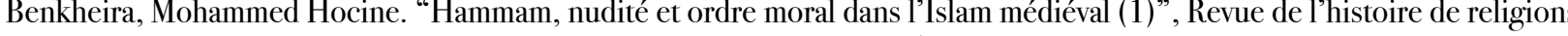
(en-ligne) 224, no. 3 (2007): 319-371, http://doi.org/10.4000/rhr.5303.

Bryan, Cyril. Ancient Egyptian Medicine: The Papyrus Ebers. Chicago: Ares Publishers, 1974.

Cagarain, Michael. The Oxford Encyclopaedia of Ancient Greece and Rome, Vol. 2. London: Oxford University Press, 2011. Childress, David. Technology of the Gods: The Incredible Sciences of the Ancients. Illinois: Adventurers Unlimited Press, 2000 .

Clement, I. Manual of Community Health Nursing. London: Jaypee Brothers Medical Publishers ,2012.

Crocker, Piers. "Status Symbols in the Architecture of El-'Amarna.", Journal of the Egyptian Archaeology 71, (1985): 52-65 Croy, Anita. Baffling Bathing Customs: The Bizarre History of Beauty. New York: Gareth Stevens Publishing, 2019.

Donnegan, James. A New Greek and English Lexicon; Principally on the Plan of the Greek and German Lexicon of Schneider Boston: Hilliard, Gray and Co., 1839.

Dove, Roja. The Essence of Perfume. London: Black Dog, 2008.

Dumreicher, Heidi. The Hammam: Scenarios for a Sustainable Future . In Gultural Heritage and Development in the Arab World, edited by Fekri Hassan, Aloisia de Trafford, and Youssef Mohsen, 229 - 242. Alexandria: Bibliotheca Alexandrina,

Ebbell, Bendix. Ebers Papyrus: The Greatest Egyptian Medical Document. London: Oxford University Press, 1973

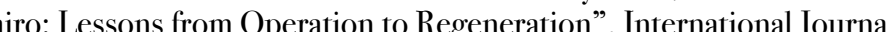
of Architectural Research 2, no 3 (2008): $29-40$.

Ermatinger, James. The World of Ancient Rome: A Daily Life Encyclopaedia. Santa Barbara: Greenwood Press, 2015. Fadli, Fodil and Sibley, Magda. “The Historic Hammāms of Cairo.” Journal of Architectural Conservation 14, no 3, (2008) 59-80.

https://doi.org/10.1080/13556207.2008.10785032. Retrieved on 4/8/2019.

Fournet, Thibaud. "The Ancient Baths of Southern Syrian in the Near Eastern Context: Introduction to Balneorient Project", in Spa Sanitas Per Aquam, Proceedings of the International Frontinus-Symposium on the Technical and Cultural History of 
Ancient Baths, edited by Ralf Kreiner and Wolfram Letzner, 327-338. Leuven: Peeters Publishers, 2009.

Fournet Thibaud, and Bérangère Redon. "Bathing in the Shadow of the Pyramids: Greek Baths in Egypt, Back to an Original Bath Model”, in Collective Baths in Egypt 2: New Discoveries and Perspectives, Études Urbaines 10, edited by Bérangère

François, Retief, and Louise Cilliers. “Medical Practices in Graeco-roman Antiquity.", Curationis 29, no. 2 (2006): 34-40 Gianfaldoni, Serena. “History of the Baths and Thermal Medicine.”, Journal of Medical Sciences 5, no. 4, (2017): 566-568.

Goitein, Shelomo Dov. A Mediterranean Society: The Jewish Community of the Arab World as portrayed in the Documents of the Cairo Geniza. Vol. 5: The Individual: Portrait of a Mediterranean Personality of the High Middle Ages as Reflected in the Cairo Geniza. Berkley, Los Angeles \& London,: University of California Press, 1988.

Golden, Mark. Sports and Society in Ancient Greece. London: Cambridge University Press, 1998.

Jones, Elizabeth. Awaken to Healing Fragrance: The Power of Essential Oil Therapy (Berkeley: North Atlantic Books, 2010

Kanawati, Naguib and Ali Hassan. "The Teti Cemetery at Saqqara, II: Tomb of Ankhmahor.", Journal of the Egyptian Archaeology 90 (2004): 231-233.

Klein, Carl. The Medical Features of the Papyrus Ebers. Chicago: American Medical Association, 1905.

Knight, Geof. Cosmetic Procedures. London: Raintree Publishers, 2011.

Lacovara, Peter. The World of Ancient Egypt: A Daily Life Encyclopaedia, Vol. 1. Santa Barbara: Greenwood Press, 2017.

Lane, Edward William. An Account on the Manners and Customs of the Modern Egyptians, The Definitive 1860 Edition. Cairo, New York:The American University in Cairo Press, 2003.

Lichtheim, Mariam. Ancient Egyptian Literature: A book of Reading: The New Kingdom, Vol. 2. Berkley: University of California Press, 1973

Manniche, Lise. Sacred Luxuries: Fragrances, Aromatherapy and Cosmetics in Ancient Egypt. New York: Cornell University Press, 1999.

Megahed, Mohamed and Hana, Vymazalova. "Ancient Egyptian Royal Circumcision from the Pyramid Complex of Djedkare.”, Anthropologie 49, no. 2, (2011):157-166.

McNeil, Sarah. Ancient Romans at A Glance.London: Peter Bedrick Books, 1998.

Olson, Kelly. Masculinity and Dress in Roman Antiquity. New York: Routledge, 2017.

Pauty, Edmond. “Les bains publics du Caire”, MIFAO 64, (1933).

Peck, William. The Material World of Ancient Egypt. New York: Cambridge University Press, 2013.

Raymond, Andre. “Les bains publics au Caire à Ia fin du XVIII siècle”, Annales Islamologiques 8, (1969): 129-165.

Raymond Faulkner and Carol Andrews. The Egyptian Book of the Dead. London: British Museum Publications, 1985) 29.

Redford, Donald. The Oxford Encyclopedia of Ancient Egypt, Vol. 2. London: Oxford University Press, 2001.

Rhind, Jennifer. Fragrance and Wellbeing: Plant Aromatics and their Influence on the Psyche. London: Jessica Kingsley Publisher, 2014.

Salisbury, Joyce. Encyclopaedia of Women in the Ancient World. Santa Barbara: Library of Congress, 2001
Shehayeb, Dina. “Survival of the Mediterranean Hammam in Contemporary Societies", HBRC (Housing and Building National Research Center) Journal Special Issue, (2010):1-17.

Sherrow, Victoria. Encyclopaedia of Hair: A Cultural History. London: Greenwood Press, 2006.

Smith, Virginia. Clean: A History of Personal Hygiene and Purity. London: Oxford University Press, 2007.

Sibley, Magda and Jackson, Iain. "The Architecture of Islamic Public Baths of North Africa and the Middle East: An Analysis of their Internal Spatial Configurations”, Architectural Research Quarterly 16, no. 2,(June 2012): 155-170.

Stephenson, Paul. The Serpent Column: A Cultural Biography. London: Oxford University Press, 2016.

Taylor, John. Journey Through the Afterlife: Ancient Egyptian Book of the Dead (London: Harvard University Press, 2010

Thomas, Ross. “Tools and Weapons”, in Naukratis: Greeks in Egypt, edited by Alexandra Villing et al., London: The British Museum, 2017. https://www.britishmuseum.org/pdf/Thomas Tools and Weapons.pdf

Trumper, Monika. "Greek Baths and Bathing Culture”, in Encyclopaedia of Global Archaeology, edited by Claire Smith et al. 784-799. New York: Springer, 2014

Tschen-Emmons, James. Artifacts from Ancient Rome. London: Greenwood Press, 2014

Tyldesley, Joyce. Daughters of Isis: Women of Ancient Egypt. New York: Penguin Putnam Inc., 1994.

University of Bonn, "Deadly medication? Scientists shed light on the dark secret of Queen Hatshepsut's flacon," PHYS. ORG, August 19, 2011. https://phys.org/news/2011-08-deadly-medication-scientists-dark-secret.html (retrieved on Septembe

Warner, Nicholas. “Taking the Plunge: The Development and Use of the Cairene Bathhouse”. In Historians in Cairo: Essays in Honor of George Scanlon, edited by Jill Edwards, 49-80. Cairo, New York:The American University in Cairo Press, 2002 Warner, Nicholas. The Monuments of Historic Cairo: A Map and Descriptive Catalogue. Cairo, New York: The American University in Cairo Press, 2004.

Wilkinson, John. Manners and Customs of the Ancient Egyptians. New York: Cambridge University Press, 2013 Woolley, Leonard. “Excavations at Tell el-Amarna.”, Journal of the Egyptian Archaeology 8, no. 1/2, (1922): 48-82. Youssef, Heba. “La Toilette Feminine a l'Epoque Fatimide en Egypte”. MSc. thesis, Helwan University, 1995. Youssef, Hussein. “Some Aspects of Public Baths in Ptolemaic and Roman Baths in Egypt.”, Bulletin of Center of Papyrological studies 20 , no. 1 (2003): 7-35 